\title{
BRASIL/PORTUGAL: POSSIBILIDADE DE UMA ESCOLA JUSTA E DAS ARTES DE FAZER O COMUM
}

Alexis de Tocqueville enxergava, em meados do século XIX, a igualdade como a corrente irresistível que assolaria todas as sociedades modernas, libertando-as das antigas hierarquias aristocráticas. Em sua ótica liberal-individualista (embora ele mesmo tenha sido um aristocrata) que mirava os Estados Unidos e via naquela sociedade em particular a apoteose do associativismo igualitário, a diferenciação se daria entre as sociedades democráticas e livres ou democráticas e despóticas. Na escolha do regime político recairia a diferenciação e o tipo de sociedade a que se almeja, visto que a igualdade de condições como processo paulatino seria inescapável. A ideia democrática, no vocabulário tocquevilliano, aparece como sinônimo de igualdade de condições de saída (oportunidades) e livre associativismo, e serviria de esteio para as diversas tradições liberais que o sucederiam.

A igualdade que o pensador francês tinha em perspectiva, contudo, não se mostrou acessível para a maior parte das sociedades desde então. Se os liames feudais se tornaram relíquias históricas, o desenvolvimento econômico e a complexificação das relações sociais trouxeram em seu bojo novas e variadas hierarquias e desigualdades. À própria concepção de igualdade, progressista e basilar em contextos nos quais se convivia com a escravidão e os direitos políticos e sociais não passavam de miragens distantes, impuseram-se outros parâmetros para a boa sociedade, como a diversidade, a pluralidade e o reconhecimento.

O que não mudou, entretanto, desde a queda do ancien régime - e duas visões se impuseram: democracia (formal) como expressão do respeito às leis, do direito à vida, à propriedade privada, à liberdade e à igualdade de oportunidades (ótica liberal) versus a visão que aponta para a mistificação e perpetuação das iniquidades via exaltação das liberdades burguesas (crítica socialista) - foi a busca por ordens societárias mais justas, ou, em termos contemporâneos, que tolerem cada vez menos as injustiças por meio de formas criativas para combatê-las. Evidentemente, a noção de justiça pode variar muito a depender do contexto social, político e histórico no qual é concebida e, sobretudo, tendo em vista o que se entende por equidade e justiça social. Nesses termos, o igualitarismo irrestrito poderia tanto representar uma armadilha, visto configurar a

\footnotetext{
${ }^{1}$ Editor científico. Docente - Faculdade de Educação. Universidade Estadual de Campinas (UNICAMP) Campinas, SP. Brasil. E-mail: acdiasjr@gmail.com
} 
antessala do despotismo (temor maior do conservador Tocqueville) como um ideal supremo a ser perseguido.

No decorrer do século XX as disputas sobre as concepções de igualdade e de justiça, e sua aplicabilidade em sistemas sociais concretos, conheceram grandes desdobramentos. Da luta pelos direitos civis e políticos, passando pela conquista dos direitos sociais e pela consecução de modelos societários cujo desenvolvimento material permitiu aos países centrais patamares inauditos de bem-estar e garantia de direitos (Welfare State), até as políticas públicas de ação afirmativa e discriminação positiva, a escola, como espaço de conflito, não ficou imune a tais desdobramentos. A sociologia da educação, em particular, tem se debruçado sobre os mecanismos de perpetuação de desigualdades que servem de obstáculo ao estabelecimento da escola justa.

Instituição da qual se espera, desde os debates sobre a instrução pública no seio do movimento revolucionário de 1789 , para além da mera instrução também o fomento para a crítica do mundo que a circunscreve, a escola acaba, muitas vezes, configurando antes um dos mais eficazes mecanismos de conservação que um vetor de mobilidade social. Não por outro motivo Pierre Bourdieu, que elaborou talvez a crítica mais contundente dos sistemas escolares que operam sob a ideologia do dom e que propagam a ideia do mérito individual deslocado das condições sociais, culturais e econômicas de origem dos estudantes, nos provocou a todos com a assertiva segundo a qual a escola justifica as desigualdades consagrando-as, visto ser uma "máquina de transformar classificações sociais em classificações escolares" ${ }^{2}$.

Tal qual as noções de igualdade, liberdade e justiça, abstratas em si e que encontram suas respectivas significações a partir da ação de homens e mulheres de carne e osso que as põem em movimento em contextos históricos específicos, a construção de práticas de justiça na escola reside, fundamentalmente, nos desafios que se apresentam cotidianamente no ambiente escolar, e de como os encaramos. Nesse sentido, o postulado dubetiano da construção da "escola o menos injusta possível" ${ }^{3}$, embora carregue uma série de contradições e limites em seu programa de ação, configure per se um ideal a ser perseguido. Afinal de contas, se não sabemos ao certo o que seria a escola justa, temos plenas condições de combater as diversas injustiças que assolam o ambiente escolar.

\footnotetext{
2 BOURDIEU, Pierre. As categorias do juízo professoral. In. NOGUEIRA, Maria Alice e CATANI, Afrânio. Escritos de Educação. Petrópolis: Vozes, 1998, p. 220.

${ }^{3}$ DUBET. François. 0 que é uma escola justa? A escola das oportunidades. São Paulo: Cortez, 2008, p. 9.
} 
O segundo número da Revista ETD - Educação Temática Digital de 2018 traz aos seus leitores e leitoras o dossiê "Brasil/Portugal: possibilidade de uma escola justa e das artes de fazer o comum", organizado pela professora Flávia Schilling e pelo professor José Manuel Rezende, a quem agradecemos vivamente por nos brindar com diferentes perspectivas sobre as artes de construir o comum em escolas brasileiras e portuguesas. Nosso leitor e nossa leitora encontrarão nos nove artigos que compõem o dossiê um conjunto de experiências que reflete tanto os desafios como as enormes possibilidades de compor o comum no plural nas escolas dos dois lados do Atlântico.

O número conta ainda com quatro artigos de demanda contínua, além de uma entrevista. A fotografia de capa, de autoria de Cristiano Barbosa, tirada em Portugal e agora publicada no Brasil, mostra território imagético composto por dois territórios, um aquático e outro terrestre (escuro e claro), que marcam as relações entre os dois países que formam o título do dossiê; um comum partilhado, no sentido de Rancière: ao mesmo tempo que separa partes, as coloca em relação.

Boa leitura! 